\title{
Simple cryoglobulinemia
}

INSERM

\section{Source}

INSERM. (1999). Orphanet: an online rare disease and orphan drug data base. Simple cryoglobulinemia. ORPHA:91139

Simple (monoclonal) cryog lobulinemia or type I cryog lobulinemia refers to the presence in the serum of one isotype or subclass of immunoglobulin (Ig) that precipitates reversibly below $37^{\circ} \mathrm{C}$. 